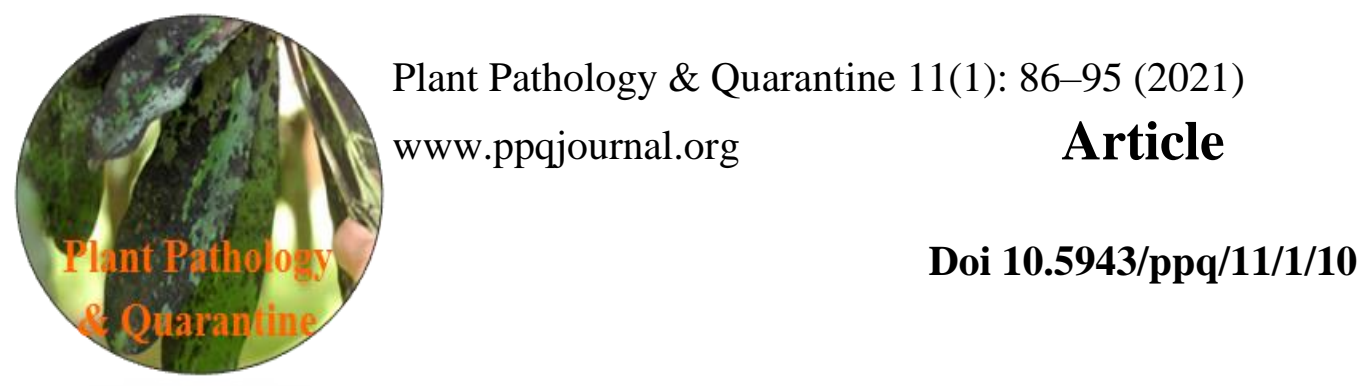

ISSN 2229-2217

\title{
What is Septoria dearnessii?
}

\section{Yeh $\mathbf{Y H}^{1}$, Wu SH${ }^{2}$ and Kirschner $\mathbf{R}^{1^{*}}$}

${ }^{1}$ School of Forestry and Resource Conservation, National Taiwan University, 10617 Taipei, Taiwan

${ }^{2}$ Taiwan Forestry Research Institute, Botanical Garden Division, Taipei, Taiwan

Yeh YH, Wu SH, Kirschner R 2021 - What is Septoria dearnessii? Plant Pathology \& Quarantine 11(1), 86-95, Doi 10.5943/ppq/11/1/10

\begin{abstract}
The coastal plant Glehnia littoralis is closely related to Angelica species and is also used as a medicinal plant in East Asia. In our study, a fungus was found on leaf spots of wild Glehnia littoralis at the sand coast of northern Taiwan. The fungus was identified as Septoria dearnessii based on three genetic markers (ITS, TEF and TUB) and morphological comparison. It is the first record for Taiwan and a new host genus record for $S$. dearnessii. An authoritative specimen collected and identified by the same persons as in the original diagnosis of the species was morphologically most similar by its $0-1$-septate conidia and, for the first time for this species, revealed a spermatial Asterostomella state. Although the ITS sequence of the Taiwanese specimen was $100 \%$ identical to the single other available published sequence from Korea, discrepancies of TEF and TUB sequences, however, in combination with the morphological variation recorded in the literature may suggest a complex of cryptic species united by closely related hosts, narrow conidia, as well as small and occasionally intercalary conidiogenous cells. 0-1-septate conidia may be diagnostic for $S$. dearnessii s. str. and frequent 3-septate conidia for one or more closely related but distinct and not yet identified species. The scarcity of DNA and morphological data of Septoria species on Apiaceae indicates the need for global revision. This case of $S$. dearnessii illustrates that identification of a "known" fungal species is often more demanding than proposing new species.
\end{abstract}

Key words - Capnodiales - fungal taxonomy - plant parasitic fungi - sand beach - Umbelliferae

\section{Introduction}

Glehnia littoralis F. Schmidt ex Miq. is the single species of its genus which is closely related to but distinct from Angelica (Liao et al. 2013). This herbaceous plant grows at sand coast sites of East Asia and North America, where it is adapted to the adverse conditions by its tolerance against salt, sand burial and wind-blown sand as well as by forming a strong tap root (Kao et al. 2010, Yang et al. 2019). By fixing the sand, the plant assists against erosion so that other plants can also establish (Yang et al. 2019). The root is widely used in East Asian medicines and occasionally as vegetable in China, Japan, Korea, and Taiwan and for this purpose also cultivated in China and Japan (Yang et al. 2019). In Taiwan, its main distribution is along the sand coasts of Kinmen and northern Taiwan (Kao et al. 2010). In its natural habitat in Taiwan, the plant is endangered by digging out for consumption (Hsu 2010). Although G. littoralis is classified as "of least concern" in the Red List of vascular plants of Taiwan (Editorial Committee of the Red List of Taiwan Plants 2017), in East Asia, the plant is generally endangered by oversampling and by destruction of the sand coast habitats (Yang et al. 2019). Cultivation of $G$. littoralis is hampered by the difficulty to break the seed dormancy (Yang et 
al. 2019). Cultivation of G. littoralis in Taiwan is promoted by the Hualien District Agricultural Research and Extension Station (Council of Agriculture 2014) and other areas of East Asia (Yang et al. 2019).

In Taiwan, the plant has a flowering season from spring to autumn and thus is an important source of nectar and pollen to the insects also living in the sand coast habitat (Kao et al. 2010). However, the insect species have not been identified, and it is not known to which degree these insects depend on G. littoralis and related Apiaceae specifically occurring at sand coasts. The fungi associated with $G$. littoralis are also poorly known. Symbiotic arbuscular mycorrhiza was abundant in G. littoralis in Japan, but the fungal species were not identified (Funatsu et al. 2005). Endophytic fungi from root, leaf and stem of this plant in China were mainly only identified to genus level, including Alternaria, Colletotrichum, Leptosphaeria, Penicillium, Stachybotrys, and Stemphylium (Hou et al. 2015). The single most likely correctly identified species was Cadophora orchidicola (Sigler \& Currah) M.J. Day \& Currah (as "Leptodontidium orchidicola Sigler \& Currah"; Hou et al. 2015). Six plant pathogenic fungal species have been recorded from G. littoralis in East Asia and North America (Farr \& Rossman 2021). During a visit of the sand coast of Gongliao District, northern Taiwan, we found leaf spots of $G$. littoralis associated with fungal infection. The aim of our study was to identify the associated fungus to species.

\section{Materials \& Methods}

\section{Collection and morphology}

The plant was identified in the flowering stage in the field. Leaves with spot disease symptoms were photographed, placed into a clean plastic bag and taken to the laboratory. Under a dissecting microscope, slimy conidial masses oozing from the pycnidia were transferred to Petri dishes containing corn meal agar (CMA, Himedia) complemented with $0.2 \%$ chloramphenicol with a flamesterilized acupuncture needle. An authoritative specimen from the same collector, the same host and identified by the original authors of the species was loaned from the National Museum of Natural Science, Taichung (TNM). Hand-made sections of leaves and conidia from cultivated material were used for morphological characterization. Measurements were made at $1000 \times$ magnifications and given as mean value \pm standard deviation of $n$ replicates with measured minimum and maximum values in brackets. Drawings of specimens stained with $1 \%$ aqueous phloxine and mounted in ca. $10 \% \mathrm{KOH}$ were made with scaled paper. Photographs were made with an Olympus EP50 camera on a light microscope at $400 \times$ and 1000× magnification. A specimen was deposited at TNM. A living strain was deposited at the Bioresource Collection and Research Center, Hsinchu, Taiwan (BCRC).

\section{Molecular analyses}

Cultivated material was used for DNA extraction. PCR with the internal transcribed spacers of the ribosomal RNA genes (ITS; including ITS1, 5.8S ribosomal rDNA, ITS2 and flanking fragments of the small and large ribosomal subunit RNA genes), primers and sequencing were performed as in Yeh \& Kirschner (2019). For amplification of the translation elongation factor 1 alpha gene (TEF) and the beta tubulin gene (TUB), the primer pairs EF1-728F/EF1-986R (Carbone \& Kohn 1999) and TUB2Fd/TUB4Rd (Groenewald et al. 2013) were used, respectively. The PCR conditions were the same as in the literature cited for the primers. After editing the DNA sequences with CodonCode Aligner version 4.0.1 (CodonCode Corporation, USA), the sequences were deposited in GenBank and the DNA Data Bank of Japan. For initial molecular identification, the sequences were submitted to BLAST searches (megaBLAST) at GenBank (https://blast.ncbi.nlm.nih.gov/).

For the taxon sampling in the phylogenetic analysis, the species of the subclade containing $S$. dearnessii in Verkley et al. (2013) and Bakhshi et al. (2019) were chosen, including two strains each of Septoria bupleuricola as more distantly related clade and of Cercospora species as outgroup (Verkley et al. 2013). For authors of scientific names of species, details of strains and sequences, see Table 1 and Verkley et al. (2013). An alignment along 798 positions was created by using MUSCLE implemented in MEGA version 7 (Kumar et al. 2016) without manual manipulation inside, but only 
cutting off the uneven ends of the alignment block. As best model, Tamura Nei model with discrete gamma distribution was chosen. The phylogenetic tree estimated by a maximum likelihood analysis with 1000 bootstrap replicates conducted with MEGA 7 (Kumar et al. 2016) was not rooted (Fig. 1).

Table 1 GenBank accessions of DNA sequences used in this study, strain and sequence data from Verkley et al. (2013), authors and orthography of scientific names from Index Fungorum (www.indexfungorum.org). New sequences in bold

\begin{tabular}{|c|c|c|c|c|}
\hline Fungus & Strain & ITS & TEF & TUB \\
\hline Cercospora apii Fresen. & CBS 118712 & KF251296 & KF253244 & KF252778 \\
\hline Cercospora zebrina Pass. & CBS 118790 & KF251300 & KF253248 & KF252782 \\
\hline Septoria aegopodina Sacc. & CBS 123741 & KF251335 & KF253282 & KF252807 \\
\hline Septoria aegopodina & CBS 123740 & KF251334 & KF253281 & KF252806 \\
\hline Septoria bupleuricola Sacc. & CBS 128603 & KF251356 & KF253303 & KF252828 \\
\hline Septoria bupleuricola & CBS 128601 & KF251355 & KF253302 & KF252827 \\
\hline Septoria campanulae (Lév.) Sacc. & CBS 128604 & KF251361 & KF253308 & KF252833 \\
\hline Septoria campanulae & CBS 128589 & KF251360 & KF253307 & KF253307 \\
\hline Septoria cf. sonchi Sacc. & CBS 128757 & KF251552 & KF253500 & KF253020 \\
\hline Septoria dearnessii Ellis \& Everh. & CBS 128624 & KF251400 & KF253347 & KF252871 \\
\hline Septoria dearnessii & $\begin{array}{l}\text { R. Kirschner } 4891 \text { = BCRC } \\
\text { FU31532 }\end{array}$ & MT843890 & LC574067 & LC574068 \\
\hline Septoria gentianae Thüm. & 28633 & KF251426 & KF253374 & KF252898 \\
\hline Septoria lactucae Pass. & $\mathrm{CE}$ & 439 & KF253387 & KF252911 \\
\hline Septoria lactucae & $\mathrm{Cl}$ & 440 & KF253388 & KF252912 \\
\hline Septoria mazi N. Naito & CBS 128755 & KF251474 & KF253422 & KF252945 \\
\hline Septoria mazi & CBS 128656 & KF251473 & KF253421 & KF252944 \\
\hline Septoria oenanthes Ellis \& Eve & CBS 128667 & KF251485 & KF253432 & KF252953 \\
\hline Septoria oenanthicola Quaedvl. et al. & CBS 128649 & KF251484 & KF253433 & KF252954 \\
\hline Septoria sii Roberge ex Desm. & CBS 102370 & KF251549 & KF253497 & KF253017 \\
\hline Septoria sii & CBS 118.96 & KF251550 & KF253498 & KF253018 \\
\hline Septoria sp. & CBS 135474 & KF251559 & KF253507 & KF253027 \\
\hline
\end{tabular}

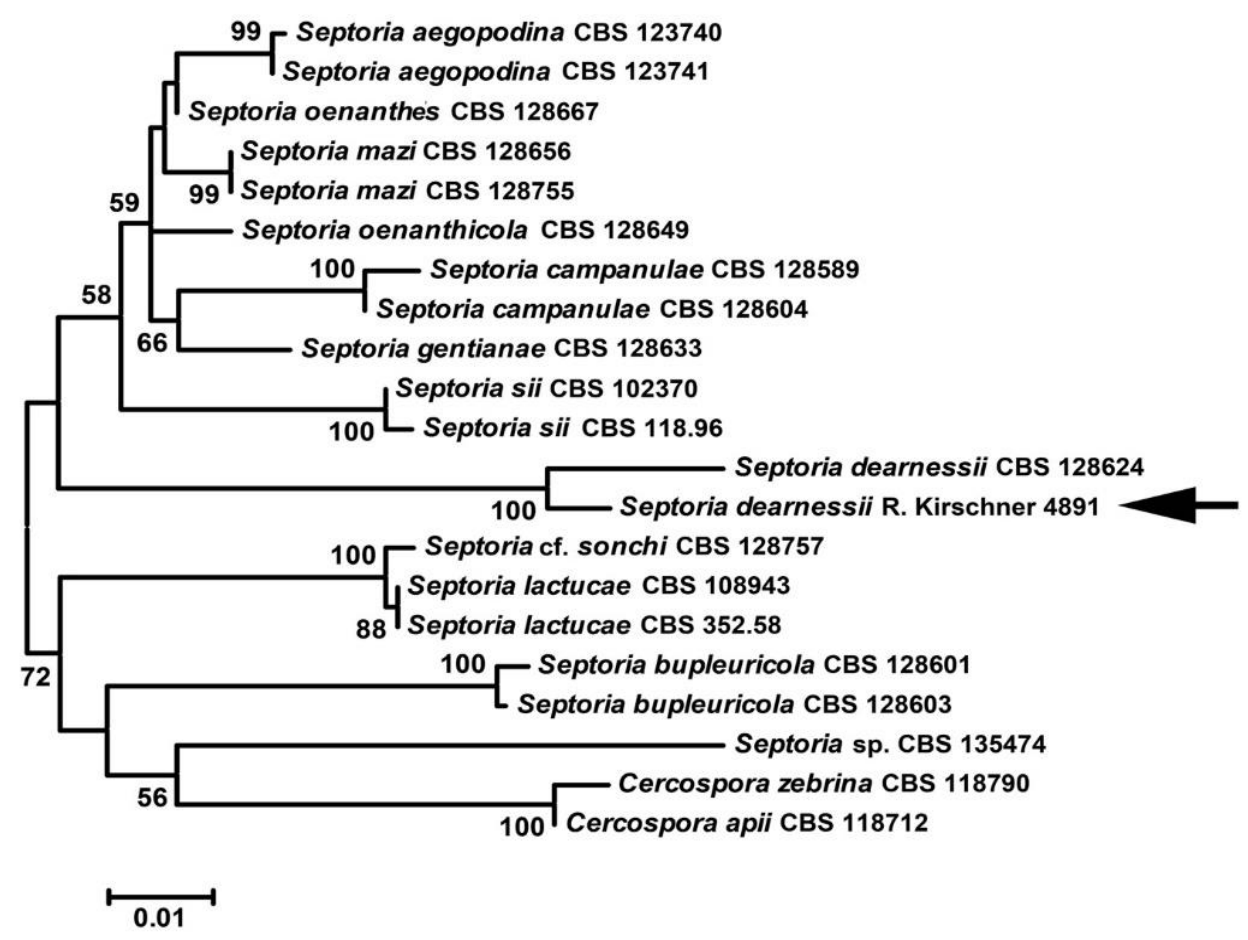

Fig. 1 - Phylogenetic tree based on the maximum likelihood analysis of a combined dataset of ITS, $T E F$, and $T U B$ sequences (with respective strain numbers) of selected Septoria species and 1000 
bootstrap replicates (values greater than $50 \%$ shown at the nodes). Two Cercospora species were chosen as outgroup. For details of the strains and sequences, see Table 1 and Verkley et al. (2013).

\section{Results}

The DNA sequences of the Taiwanese specimen were most similar to those of the single isolate of Septoria dearnessii (CBS 128624). This strain was isolated from Angelica dahurica in Korea (Verkley et al. 2013). Both ITS sequences (534 bp) were 100\% identical. Two further unpublished sequences from $S$. dearnessii from China (GenBank KC874672 and KC874673) had 99\% identity (517/518 and 522/525 bp, respectively). Because of the unpublished status and lack of other markers, those two sequences were not included in the phylogenetic analysis. The second highest identity among sequences exceeding $530 \mathrm{bp}$ with $99 \%$ ( 2 different positions, 535/537 bp, no gaps) was shown for two strains of $S$. mazi, which formed a separate clade in the phylogenetic analysis of three genes (Fig. 1). The TUB sequences had $94 \%$ (289/309 bp, no gaps) identity, whereas the identity with other species was $89 \%$ or lower. The TEF sequences were $93 \%(213 / 228 \mathrm{bp})$ identical with a query cover of $83 \%$, while the query cover with other strains was less than $30 \%$. From the identities of the DNA sequences, we conclude that the fungus from $G$. littoralis was $S$. dearnessii or a closely related species. In the phylogenetic analysis, the two strains of $S$. dearnessii formed a strongly supported clade with $100 \%$ bootstrap value (Fig. 1). The clade composed of the two sequences of S. dearnessii was highly supported, though with different branch lengths. In some other species, where also two sequences were included, branch lengths differed from species to species, e.g. without difference in S. lactucae, but being different in S. bupleuricola (Fig. 1).

As discussed below, few data are available for S. dearnessii and other species on Angelica and most closely related genera (Archangelica, Glehnia, Ostericum). The descriptions of $S$. dearnessii considerably vary (Table 2). For these reasons, we compared the morphology of an authoritative specimen of $S$. dearnessii (Table 2), which revealed to be most similar to the fungus on G. littoralis.

Septoria dearnessii Ellis \& Everh., J. Mycol. 5(3): 151 (1889)

Figs $2-3$

Specimen Kirschner et al. 4891 on Glehnia littoralis, Taiwan

Fig. 2

Leaf spots amphigenous, pale to dark brown, angular by being limited through leaf veins, first separated and few mm diam., then becoming confluent and dotted by regularly spaced blackish pycnidia. Internal hyphae intercellular in mesophyll, hyaline, 1-3 $\mu \mathrm{m}$ wide. Pycnidia amphigenous, developing below epidermis, subglobose, unilocular, dark brown, (55-)65-100(-105) $\mu \mathrm{m}$ diam. $(\mathrm{n}=$ 10), wall composed of ca. 2-3 medium brown cell layers. Ostiole rupturing through the epidermis, circular, 20-30 $\mu \mathrm{m}$ diam., surrounding cells with same color as pycnidial wall. Conidiophores 1-3celled, irregular, conspicuously constricted at septa or without constrictions. Conidiogenous cells in some cases intercalary, more conspicuously ones terminal, variable in shape, hemispherical, ampulliform, to cylindrical, 3-6 $\times 1.5-4 \mu \mathrm{m}$, terminating into one or rarely two ca. $1 \mu \mathrm{m}$ long beaks, whose apices become truncate after conidium dehiscence, no annellations visible. Conidia cylindrical, straight to slightly curved or slightly undulate, hyaline, smooth, narrowing to both ends, base inconspicuously truncate, $1 \mu \mathrm{m}$ wide, apex rounded, $0-1$-septate (in old culture exceptionally 2 -septate), $(11-) 15-23(-32) \times 1.5 \mu \mathrm{m}(\mathrm{n}=30)$, in culture $(9-) 12-18(-20) \times 1.5(-2) \mu \mathrm{m}(\mathrm{n}=30)$.

Colony on CMA - Slow-growing, few millimeters per month, dark brown on both sides, on the upper side with thin, irregularly feathery, creamy-white mycelium and dark brown pycnidia and creamy-whitish slimy conidial masses, no diffusing pigment.

Material examined - On diseased living leaves of Glehnia littoralis F. Schmidt ex Miq. (Apiaceae), Taiwan, New Taipei City, Gongliao District, sand coast, ca. 25.033146, 121.932084, 21 February 2020, Roland Kirschner, Shu-Hui Wu \& Yu-Wei Yeh 4891 (TNM). Living strain: BCRC FU31532. DNA sequences generated by Yu-Hung Yeh (GenBank accessions): ITS MT843890, TEF LC574067, TUB LC574068. 

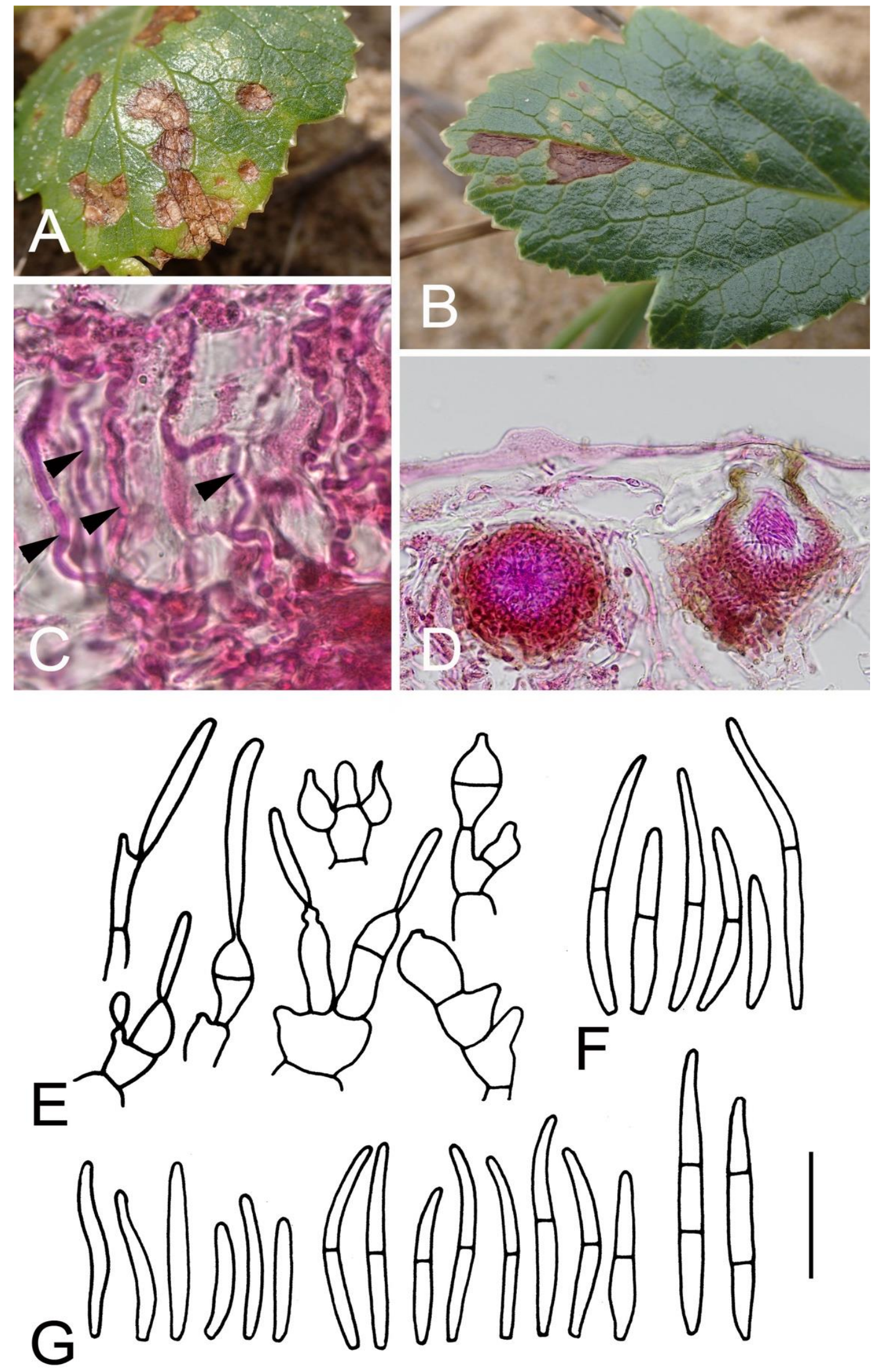

Fig. 2 - Septoria dearnessii on Glehnia littoralis (R. Kirschner 4891). A, B Leaf spots. C, D Details of transversal leaf sections showing intercellular hyphae in mesophyll (arrowheads) (C) and pycnidia developing below the epidermis ( $D$, left), eventually with ostiole rupturing epidermis ( $D$, right). E, F Microscopic characteristics from natural substrate. E Conidiophores. F Conidia. G Conidia from culture on CMA. Scale bar $=10 \mu \mathrm{m}$. 
Specimen J. Dearness 2662 on Archangelica atropurpurea, Canada

Fig. 3

Leaf spots angular by vein-limiting, $0.5 \times 1 \mathrm{~mm}$, confluent to up to ca. $5 \mathrm{~mm}$. Sporomata aggregated on abaxial side of leaf spots, almost black under dissecting microscope, medium brown under the light microscope, ca. 50-90 $\mu \mathrm{m}$ high, $75-125 \mu \mathrm{m}$ wide, mostly sterile, loosely filled with hyaline to pale pseudoparenchymatic cells, in two cases producing macroconidia, in two other cases producing spermatia/microconidia. Hyphae intercellular, hyaline to pale brown, smooth, 2-6 $\mu \mathrm{m}$ wide. Conidiophores of macroconidia reduced to conidiogenous cells or up to 3-celled. Conidiogenous cells intercalary and terminal, variable in shape, hemispherical, ampulliform, to cylindrical, $(5-) 5.5-8(-10) \times(1.5-) 2-3.5(-4) \mu \mathrm{m}(\mathrm{n}=20)$, often terminating into up to ca. $2 \mu \mathrm{m}$ long beak, in some with up to three apical and subapical apparently sympodial proliferations. Conidia cylindrical, straight to slightly curved or slightly undulate, narrowing to both ends, hyaline, smooth, 0-1-septate (only 2 conidia 2 -septate), 0 -septate $(15-) 23-32(-35) \times 1-1.5 \mu \mathrm{m}(\mathrm{n}=30), 1$-septate $(16-) 22-33(-36) \times 1-1.5 \mu \mathrm{m}(\mathrm{n}=25), 2$-septate $27-32 \times 1.5 \mu \mathrm{m}(\mathrm{n}=2)$. Spermatogenous cells ampulliform, terminal, 3-5 $\times 2-3 \mu \mathrm{m}$, spermatia ellipsoidal, oblong, cylindrical, straight to curved, hyaline, smooth, $3-4 \times 0.5-2 \mu \mathrm{m}$.
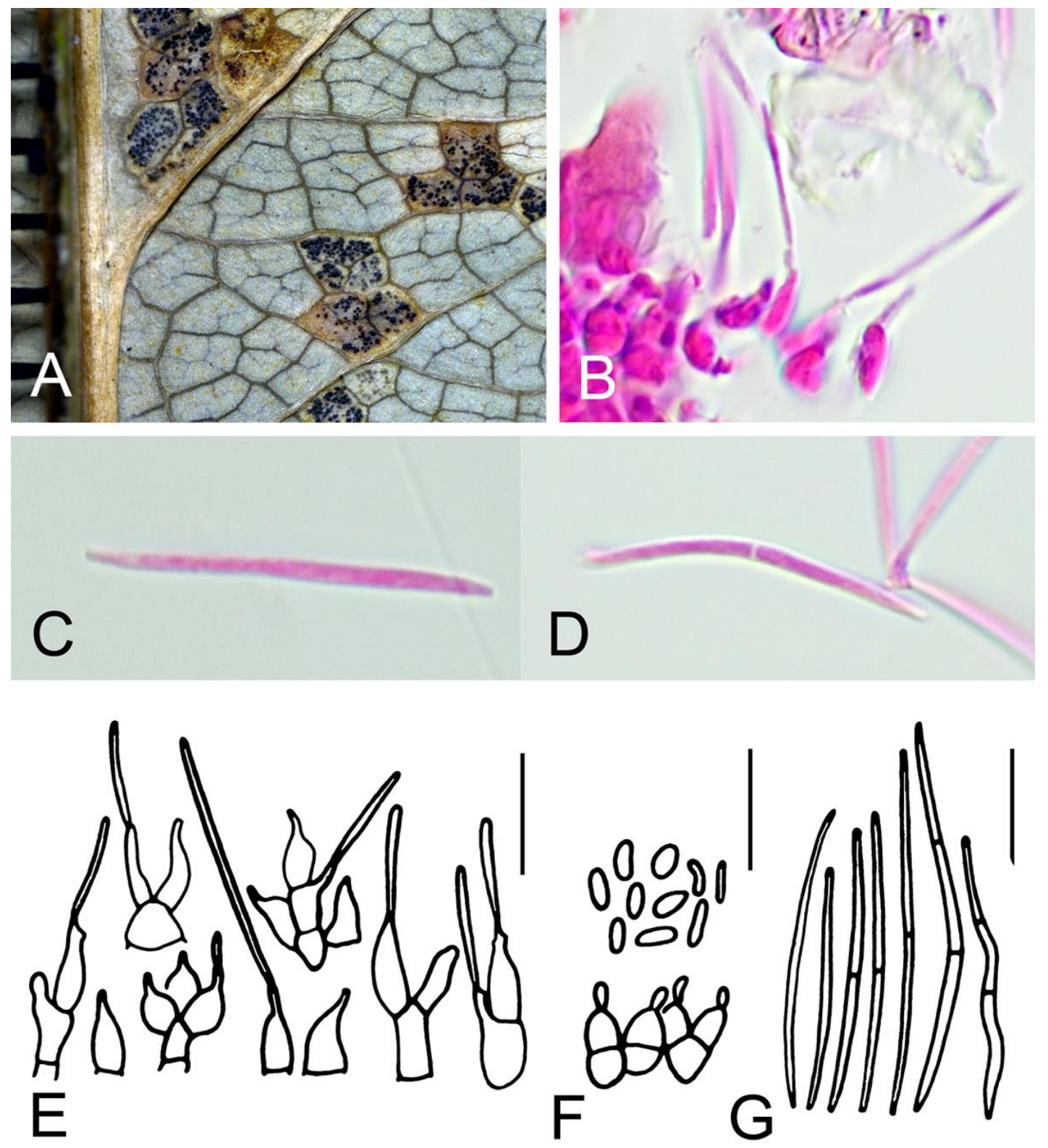

Fig. 3 - Septoria dearnessii on Archangelica atropurpurea (J. Dearness 2662, TNM F0011848). A Abaxial leaf surface with sporomata on leaf spots seen with dissecting microscope (mm scale on 
the left side). B Conidiophores. C Aseptate conidium. D 1-septate conidium. E Conidiophores with terminal and intercalary conidiogenous cells. F Spermatogenous cells and spermatia. G Conidia. Scale bars $=10 \mu \mathrm{m}$.

Material examined - On leaf spots of Archangelica atropurpurea L. (= Angelica atropurpurea (L.) Hoffm.), Canada, September 1889, J. Dearness 2662, det. J.B. Ellis \& M.B. Everhart (TNM F0011848).

Notes - The specimen was not identical with the type specimen of the protologue but authoritative by the same collector (J. Dearness), the same host, the same country and identification by the same authors (J.B. Ellis \& M.B. Everhart) in the same year of publication of the species.

Hosts reported in the literature - Angelica biserrata (R.H. Shan \& C.Q. Yuan) C.Q. Yuan \& R.H. Shan (= A. pubescens fo. biserrata R.H. Shan \& C.Q. Yuan), A. cincta H. Boissieu (= A. amurensis Schischk.), A. dahurica (Fisch.) Benth. \& Hook. f., A. sylvestris L., A. triquinata Michx., Archangelica atropurpurea L. (= Angelica atropurpurea (L.) Hoffm.), Ostericum grosseserratum (Maxim.) Kitag. (= O. koreanum (Maxim.) Kitag.), O. sieboldii var. praeteritum (Kitag.) Y.H. Huang (= O. praeteritum Kitag.), Angelica keiskei Koidz. (Takeuchi \& Horie 1995, Bai 2003, Yu et al. 2003, Shin \& Sameva 2004, Farr \& Rossman 2021; plant names updated with www.tropicos.org followed by the older name used in the references in brackets), and Glehnia littoralis (new host).

Geographical distribution reported in the literature - Europe: Austria, Bulgaria, England, Germany, Russia; America: Canada, USA; Asia: Mainland China, Korea, Japan (Bai 2003, Shin \& Sameva 2004, Farr \& Rossman 2021), Taiwan (new record).

\section{Discussion}

\section{Molecular identification of Septoria}

The fungus was identified as Septoria dearnessii. Septoria in the past contained 3000 species (Verkley et al. 2013). Although many of them have been transferred to other genera, our knowledge of many species is still poor. Despite the worldwide distribution and history of over 120 years of the fungi recorded as $S$. dearnessii, hitherto only sequences of a single published strain of this species existed. The commonly used ITS barcode for resolving species in fungi retrieved $100 \%$ identity with a strain from Korea and two unpublished strains from mainland China. The sequences of $T E F$ and $T U B$ also referred to the Korean strain, but only with identities of 93 to $94 \%$. This discrepancy indicates a complex of cryptic species. Cryptic species, however, are usually resolved with considerably more data than available in this case, i.e. BLAST searches yield $100 \%$ identity for a $100 \%$ coverage against a broad range of ITS sequences from different cryptic species. In contrast, other genes such as TUB allow sufficient resolution (Hofstetter et al. 2019). Analyses including the sequences from the Korean strain of " $S$. dearnessii" suggested its most basal position in the most basal clade of the genus in Verkley et al. (2013), whereas in Bakhshi et al. (2019) it nested among other Septoria clades. The subclade containing "S. dearnessii", however, was composed of almost the same species in both studies, which were taken up here without aiming a resolution of the interspecific relationship.

\section{Morphological discrepancies in the descriptions}

The wide geographic distribution recorded in the literature is based on the assumed host specificity on Angelica and related genera and comparatively narrow conidia with less than five septa. Conidiophores and conidiogenous cells of the Taiwanese specimen were somewhat unusual for Septoria, because conidiophores were not merely reduced to single conidiogenous cells lining the inner wall of pycnidia, and conidiogenous cells were relatively small, not exceeding $10 \mu \mathrm{m}$ in length (Verkley et al. 2013). Descriptions of conidiophores and conidiogenous cells were rarely given for S. dearnessii. In contrast to Bai (2003) describing the conidiogenous cells (= conidiophores?) as branched, 5-8 x 3-5 $\mu \mathrm{m}$, and illustrating unbranched conidiophores, Wang et al. (2018) reported small conidiogenous cells (as "conidiophores") measuring $1-4 \times 1-3 \mu \mathrm{m}$ and in their photographs 
illustrated intercalary conidiogenous cells of 2- to 3-celled conidiophores. Although conidiophores in many Septoria species are reduced to the conidiogenous cells lining the inner wall of the pycnidium (Quaedvlieg et al. 2013), 2- or more-celled conidiophores with an intercalary conidiogenous cell occur in some species, e.g. S. cucubali Lebedeva, S. leucanthemi Sacc. \& Speg., S. matricariae Hollós, and S. stellariae Roberge ex Desm. (Verkley et al. 2013). None of the cited descriptions of S. dearnessii mentioned the spermatial stage which was found in the authoritative specimen in this study. The spermatial stage is occasionally found in other Septoria species and assigned as Asteromella stage (Verkley et al. 2013). The taxonomical potential for species separation is low because of low morphological variation (Sutton 1980). The spermatogonia precede the development of the Mycosphaerella teleomorph (Sutton 1980). The most dominant structures in the authoritative specimen were sterile and may represent infertile stages of the teleomorph, yet unknown for $S$. dearnessii. The ITS sequence of the Taiwanese specimen with 0-1(-2)-septate conidia was 100\% identical to that from Korea. Specimens from Korea were described to produce 1-3-septate conidia (Shin \& Sameva 2004). In the records of $S$. dearnessii, conidial width is quite constantly given as 1.5-2 $\mu \mathrm{m}$, whereas lengths differ between specimens (Table 2) and between material from the leaf and from culture. The number of septa per conidium given in the literature is less than five, but differs between different descriptions (Table 2). In the Taiwanese specimen, whether conidia were aseptate or 1-septate appeared to be dependent on the age of the pycnidium, since in one slide conidia were only aseptate, whereas in another slide they were predominantly 1-septate. Nevertheless, more than one septum per conidium was only exceptionally found in an old culture. The contrary reports of specimens (Table 2) with 3- and 4-septate conidia from East Asia may indicate the presence of one or more yet unidentified species.

Table 2 Characteristics of conidia and conidiophores of Septoria dearnessii as described and illustrated from leaf preparations in the literature (chronologically arranged)

\begin{tabular}{|c|c|c|c|c|}
\hline Conidium size $(\mu \mathrm{m})$ & $\begin{array}{l}\text { Conidium } \\
\text { septa, number }\end{array}$ & Conidiophores & $\begin{array}{l}\text { Conidiogenous cells, } \\
\text { size }(\mu \mathrm{m})\end{array}$ & Reference \\
\hline$(11-) 15-23(-32) \times 1.5$ & $\begin{array}{l}0-1(-2, \text { in } \\
\text { culture })\end{array}$ & 1-3-celled & $3-6 \times 1.5-4$ & $\begin{array}{l}\text { This study: on } G \text {. } \\
\text { littoralis }\end{array}$ \\
\hline $\begin{array}{l}1 \text {-septate }(15-) 23-32(- \\
35) \times 1-1.5 ; 2 \text {-septate } \\
(16-) 22-33(-36) \times 1-1.5\end{array}$ & $0-1(-2)$ & 1-3-celled & $\begin{array}{l}(5-) 5.5-8(-10) \times \\
(1.5-) 2-3.5(-4)\end{array}$ & $\begin{array}{l}\text { This study: J. } \\
\text { Dearness 2662, det. } \\
\text { Ellis \& Everhart } \\
\text { (1889) }\end{array}$ \\
\hline $15-22 \times 1.5$ & 0 & Not given & Not given & $\begin{array}{l}\text { Ellis \& Everhart } \\
\text { (1889) }\end{array}$ \\
\hline $13-40 \times 1.5-2.5$ & $0-4$ & Not given & Not given & $\begin{array}{l}\text { Takeuchi \& Hori } \\
\text { (1995) }\end{array}$ \\
\hline $14-28 \times 1-2$ & $1-5$, mostly 3 & Single-celled & $\begin{array}{l}5-8 \times 3-5 \text {, confused } \\
\text { with conidiophores? }\end{array}$ & Bai (2003) \\
\hline Not given & $1-3$ & Not given & Not given & Yu et al. (2003) \\
\hline $15-36 \times 1-1.5(-2)$ & $\begin{array}{l}0, \text { sometimes } \\
1-2\end{array}$ & Not given & Not given & Sameva (2004) \\
\hline $\begin{array}{l}18-36(-48) \times 1.5-2.0(- \\
3.0)\end{array}$ & $1-3$ & Not given & Not given & $\begin{array}{l}\text { Shin \& Sameva } \\
\text { (2004) }\end{array}$ \\
\hline $12-26 \times 1.5-2$ & $\begin{array}{l}1-3, \\
\text { illustration: } \\
\text { mostly } 1 ?\end{array}$ & 2-3-celled & $\begin{array}{l}1-4 \times 1-3 \text {, confused } \\
\text { with conidiophores }\end{array}$ & Wang et al. (2018) \\
\hline
\end{tabular}

\section{Conclusion on the species identification}

A frequently encountered problem in fungal taxonomy is the presence of species complexes and the lack of revision of old species. Because of the maximum $94 \%$ identity of TEF and TUB (in contrast to the $100 \%$ ITS identity) and the above-mentioned discrepancies of the morphological descriptions, the sequences labeled in GenBank as Septoria dearnessii may represent not this but other species of Septoria. Most of the over 3000 taxa described in Septoria have not been revised 
(Verkley et al. 2013). Molecular identification of S. protearum Viljoen \& Crous on six host families of seed plants and ferns is challenging the traditional belief in host-family specificity of Septoria species (Verkley et al. 2013). Septoria species on Apiaceae are scattered in different clades that contain species on other host families, which proves that instead of the previously assumed fungusplant coevolution, frequent host jumps occurred in the speciation in Septoria (Verkley et al. 2013).

In spite of this new understanding, new species are recently proposed based on the traditional assumption of narrow host ranges (Bakhshi et al. 2019). Shin \& Sameva (2004) mentioned $S$. angelicae Höhn. and S. xanthogali Mekht. both from Angelica hosts as most similar species and suggested further study for clarifying the species boundaries or possible synonymies. This revision should include the type specimens and freshly isolated strains from the type localities. The case of $S$. dearnessii illustrates that identification of a fungus with a known scientific binomial name is often more demanding than simply proposing new species.

\section{Ecological and phytopathological significance of the findings}

Septoria fungi were reported as important pathogens of cultivated medicinal Angelica species in mainland China, Korea, and Japan (Yu et al. 2003, Shin \& Sameva 2004, Zheng et al. 2007). In Taiwan, A. keiskei was introduced from Japan in 1987 and since then has become widely cultivated as vegetable and medicinal plant (Hsueh 2000, Hsueh \& Yang 2012). Growth and germination experiments with Septoria fungi indicated that temperature was one of the most influential factors, with an optimum at $25^{\circ} \mathrm{C}$ (Zheng et al. 2007, Wang et al. 2018). The specimen in Taiwan was collected in February, prior to the onset of high summer temperatures. For G. littoralis, S. dearnessii is the seventh pathogenic fungus recorded on this host. However, there are no sufficient data whether the fungus is common or rarely associated with $G$. littoralis. Records of $S$. dearnessii on wild and cultivated Angelica species in Taiwan can be expected for the next future. The random collection of a Septoria species from an important medicinal plant at the easternmost coast of Taiwan island illustrates our generally highly fragmentary knowledge about fungi and sand coast ecosystems.

\section{Acknowledgements}

The study was supported by the Ministry of Science \& Technology, Taiwan (MOST 108-2621B-002-007). We thank Ms. W.-T. Lin for guidance to the collection site at Gongliao, C. Glatthorn and M. Piepenbring, Frankfurt am Main, Germany, for help with the literature, and M. Arzanlou, Tabriz, Iran, for critical feedback to an early version of the manuscript. The curators and keepers at TNM are thanked for the specimen loan.

\section{References}

Bai JK. 2003 - Flora fungorum sinicorum. Vol. 17. Sphaeropsidales: Ascochyta Libert, Septoria Saccardo. Science Press, Beijing (in Chinese).

Bakhshi M, Arzanlou M, Zare R, Groenewald JZ, Crous PW. 2019 - New species of Septoria associated with leaf spot diseases in Iran. Mycologia 111(6), 1056-1071.

Carbone I, Kohn LM. 1999 - A method for designing primer sets for speciation studies in filamentous ascomycetes. Mycologia 91, 553-556.

Council of Agriculture, Executive Yuan. 2014 - The cultivation and usage of Glehnia littoralis. https://kmweb.coa.gov.tw/subject/subject.php?id=37472 (in Chinese).

Farr DF, Rossman AY. 2021 - Fungal Databases, U.S. National Fungus Collections, ARS, USDA. https://nt.ars-grin.gov/fungaldatabases

Editorial Committee of the Red List of Taiwan Plants 2017 - The Red List of Vascular Plants of Taiwan, 2017. Endemic Species Research Institute, Forestry Bureau, Council of Agriculture, Executive Yuan and Taiwan Society of Plant Systematics.

Ellis JB, Everhart BM. 1889 - New and rare species of North American Fungi (Sphaeropsidae). The Journal of Mycology 5(3), 145-157. 
Funatsu Y, Nakatsubo T, Yamaguchi O, Horikoshi T. 2005 - Effects of arbuscular mycorrhizae on the establishment of the alien plant Oenothera laciniata (Onagraceae) on a Japanese coastal sand dune. Journal of Coastal Research 21(5), 1054-1061.

Groenewald JZ, Nakashima C, Nishikawa J, Shin H-D et al. 2013 - Species concepts in Cercospora: spotting the weeds among the roses. Studies in Mycology 75, 115-170.

Hofstetter V, Buyck A, Eyssartier G, Schnee S, Gindro K. 2019 - The unbearable lightness of sequenced-based identification. Fungal Diversity 96, 243-284.

Hou XQ, Ren XY, Fu YJ, Wang H et al. 2015 - Study on antibacterial activity and classification of endophytic fungi from Glehnia littoralis. Chinese Traditional and Herbal Drugs 46(19), 2932 2936 (in Chinese).

Hsu C-H. 2010 - Glehnia littoralis. https://blog.xuite.net/hsu042/twblog1/122927965-\%E6\%BF\%B1\%E9\%98\%B2\%E9\%A2\%A 8 (in Chinese).

Hsueh C-H. 2000 - The encyclopedia of vegetables and fruits in Taiwan (2). United Distribution, Hsindian (in Chinese).

Hsueh C-H, Yang Z-Y. 2012 - The scenic plants in Taiwan (4). United Distribution, Hsindian (in Chinese).

Kao R-Q, Wu S-H, Zhang YZ. 2010 - Illustrated guide to coastal plants of Taiwan. Morning Star Group: Taichung (in Chinese).

Kumar S, Stecher G, Tamura K. 2016 - MEGA7: Molecular Evolutionary Genetics Analysis version 7.0 for bigger datasets. Molecular Biology \& Evolution 33, 1870-1874.

Liao C, Downie SR, Li Q, Yu Y et al. 2013 - New insights into the phylogeny of Angelica and its allies (Apiaceae) with emphasis on East Asian species, inferred from nrDNA, cpDNA, and morphological evidence. Systematic Botany 38(1), 266-281.

Quaedvlieg W, Verkley GJM, Shin HD, Barretto RW et al. 2013 - Sizing up Septoria. Studies in Mycology 75, 307-390.

Sameva EF. 2004 - New records of anamorphic fungi from Bulgaria. Mycologia Balcanica 1, 5557.

Shin HD, Sameva EF. 2004 - Septoria in Korea. National Institute of Agricultural Science and Technology, Suwon, Korea.

Sutton BC. 1980 - The Coelomycetes. Fungi imperfecti with pycnidia, acervuli and stromata. Commonwealth Mycological Institute, Kew, Surrey, England.

Takeuchi J, Horie H. 1995 - The first report of leaf spot on Angelica keiskei caused by two species of Septoria in Japan. Proceedings of the Kanto-Tosan Plant Protection Society 42, 111-113 (in Japanese).

Verkley GJ, Quaedvlieg W, Shin HD, Crous PW. 2013 - A new approach to species delimitation in Septoria. Studies in Mycology 75(1), 213-305.

Wang Y, Jin L, Zeng C-y, Luo J, Chen H-g. 2018 - Pathogen identification and biological characteristics of spot blight in Angelica dahurica in Gansu Province. Journal of Gansu Agricultural University 53(6), 143-149 (in Chinese).

Yang M, Li X, Zhang L, Wang C et al. 2019 - Ethnopharmacology, phytochemistry, and pharmacology of the genus Glehnia: A systematic review. Evidence-Based Complementary and Alternative Medicine Article ID 1253493, 33 pages. Doi 10.1155/2019/1253493

Yeh Y-H, Kirschner R. 2019 - A new species of Alpestrisphaeria (Dothideomycetes) with monodictys-like anamorph and revision of three Monodictys species. Mycological Progress 18, 703-711.

Yu DZ, Wang SN, Yang XJ, Yang LJ, Zhang HY. 2003 - Studies on identification and control of an important disease from Angelica pubescens Maxim. f. biserrata. Hubei Agricultural Sciences 2003(4), 74-75 (in Chinese).

Zheng Y, Ye H-Z, Yan J-M. 2007 - Studies on biological characteristics of Septoria dearnessii. Southwest China Journal of Agricultural Sciences 20(5), 1007-1011 (in Chinese). 